\title{
Determinants of Women's Non-family Work in Ghana and Zimbabwe
}

\author{
Kofi D. Benefo \\ Sociology Department \\ Lehman College \\ New York, New York \\ Vijayan K. Pillai \\ School of Social Work \\ University of Texas at Arlington \\ Arlington, Texas
}

\begin{abstract}
One objective of this paper is to evaluate the determinants of female non-family work in Africa. Selected labor force participation theories are tested using demographic and health survey data. The traditional kinship-oriented family organization in Africa, along with high fertility, have long been seen as factors that constrain women's participation in the labor force, particularly in seeking formal sector employment. We use demographic and health survey data from two African countries, Ghana and Zimbabwe. Education emerges as the most important determinant of non-family work. Even if female education levels increase, single women may not gain easy entry into the informal economy managed by kinshipbased social networks. A large proportion of these educated women may not find jobs if the formal economy does not expand. Results from Ghana and Zimbabwe are compared.
\end{abstract}

Key Words: Female non-family work, Africa, Ghana, Zimbabwe, female labour force participation. 
Kofi D. Benefo and Vijayan K. Pillai

\section{Résumé}

Un des objectifs de cet article consiste à évaluer les déterminantsdu travail féminin hors famille en Afrique. Les théories au sujet de la population active sélectionnée sont éprouvées au moyen de données démographiques et de sondages sur la santé. La structure familiale traditionnelle fondée sur la parenté en Afrique, alliée à un taux de fertilité élevé, a toujours été considérée comme un facteur limitant la participation des femmes à la population active, surtout en ce qui concerne la recherche d'emplois sur le marché officiel. Nous avons utilisé les données démographiques et de sondages sur la santé de deux pays africains, à savoir le Ghana et le Zimbabwe. L'éducation ressort comme étant le déterminant de loin le plus important relativement à un travail hors famille. Même si les niveaux d'éducation des femmes s'améliorent, les femmes célibataires n'ont pas facilement accès au marché informel géré par des réseaux sociaux fondés sur la parenté. Une grande proportion de ces femmes éduquées ne trouvera pas de travail si le marché officiel ne s'élargit pas. Une comparaison des résultats du Ghana et du Zimbabwe y est donnée.

Mots-clés : travail féminin hors famille, Afrique, Ghana, Zimbabwe, participation féminine à la population active.

\section{Introduction}

Perhaps one of the most noticeable social trends of the latter half of the twentieth century was an increase in female labor force participation in both developing and developed countries. The duration of swing upwards in the female labor force participation varies significantly across regions. African women have a long history of labor force participation. However, even in Africa, female labor force participation, especially non-family employment, is constrained by many social and economic forces. It is well known that female labor force participation is a strong component of women's status globally (Haghighat, 2002; Khattab, 2002; Parrado \& Zenteno, 2001; Togunde, 1999b; Jibou, 1988). Non-familyemployment is defined as work organized outside the control and ownership of the kin group. The literature on African women shows that when they have participated in nonfamily work, they have translated their earnings into family planning usage, adopted modern child care methods and considerably improved their own welfare and that of their own households (Safilios-Rothschild, 1985). They have also developed new supports in kinship- and non-kinship based networks and reduced their dependenceon their husbands with resourcesacquired in non-familyeconomic activity (Ettiene, 1983; Lewis, 1977; Leis, 1974). 
Existing theories on female labor force participation in Africa have not been adequately tested. Furthermore, previous studies of African women's work have been largely ethnographic and descriptive. As a result they have not consistently distinguished the relative importance of the determinants of women's economic activity in developing countries(Boserup, 1970; Charter, 1981; Schildkrout, 1979, 1989; Sudarkasa, 1982). In the policy field, this has resulted in the determination of foci based on the experience of the Western world. This study has two objectives. The first is to examine the determinants of female non-family work in Africa. Toward this end, we evaluate three theories of female labor force participation using demographic and health survey data. The second objective is to assess the validity of our findings through replication of the study using data from another country in Africa. We use demographic and health survey data from two African countries, Ghana and Zimbabwe. Two considerations prompted the selection of these countries. First, socio-demographic data for these countries were readily available. Second, Ghana and Zimbabwe differed significantly with respect to their level of development. The World Bank ranked 130 countries according to their score on the Human Development Index (HDI). All countries in Africa fell below the HDI scale midpoint. Ghana, with a rank of 30, falls in a group of countries with ranks below the 25 percent point of the HDI scale. Zimbabwe has a rank of 52 and falls in the second quartile range of the HDI scale. In terms of socio-economic development, Ghana and Zimbabwe represent two dissimilar contexts of development. Ghana is far less developed than Zimbabwe. The demographic and health surveys, because they collectedcomparable information for a number of countries, allow analysis of the influences of both structural and individual level processes on women's economic activity.

\section{Conceptual Framework}

The literature on female non-family work participation (female work participation) suggests three prominent arguments. The first, suggests that female work participation is a function of family organization. (Ogawa \& Ermish, 1996; Afonja, 1981; Peil,1972; ILO, 1964). The kinship system forms the basis of family organization. Especially in rural Africa, property relations, economic and legal obligations and political relations are determined by the kinship system. In urban areas, the kinship system is as strong as it is in the rural areas (Nukunya, 1992). Among the Akans, the largest ethnic group in Ghana, the matrilineal system of kinship is the most common form of family organization (Sarpong, 1974). The most important characteristic of family organization is its nature of headship. In particular, when the household is headed by a female, women are less likely to be constrained by males who benefit from controlling female labor (Pedersen, 1987; Sanjek ,1982; Kossoudji \& Mueler, 1981). A variety of marital statuses characterize the head of the household. The household head may be a married male, a married female, a single parent, or previously married (Kanduza, 1988). In a few 
households, the family may include more than one married male or female. In such instances, the family may be headed by any one of the married males or females. There are varieties of these kin relationships. Migration and increases in marital dissolution have weakened the conjugal relationship and resulted in the phenomenon of households headed by married females. These women are often without access to male-dominated resources provided by the conjugal relationship. In rural areas, these women may be able to substitute with access to the kin relationship. Nukunya (1975) observes for the Ewe in Ghana, that female headed households are highly complex. In the urban area, even access to kin relationships may be problematic. In sum, it is hypothesized that the propensity to work outside of the household may be higher when the head of the household is a female rather than a male (Kanduza, 1988; Jensen, 1995).

A second argument, the human capital theory, attributes women's participation in non-family work to their level of schooling. Formal schooling exposes women to the norms of economic institutions of production and consumption and provides skills necessary to access opportunities and to access the labor market and participate in the labor force (Naude \& Serumaga-Zake, 2001; Togunde,1999a; Abu-Hussein, 1994; Junsay \& Heaton, 1989). The human capital approach emphasizes characteristics of the individual as important determinants of work. As a result, as the number of years of schooling increases, the likelihood of participation in non-family work increases.

A third, identifies fertility as an important determinant of women's non-family work. The number of children, especially the presence of young children - children less than five years old-presents a barrier to women's non-family work participation (Edwards, 1996; Adepoju, 1994; Lewis, 1977). Available empirical evidence does not fully support this view. Alternatively, some suggest that childbearing impediments are not important barriers to work because women are able to manage large family sizes and high work rates by obtaining child care assistance from relatives, and human capital investment is not important for work in the informal sector where most women are located (Togunde,1999b; Mueller, 1982; Standing \& Sheehan, 1978; Stycos \& Weller, 1967). However, these studies have focused on women employed in informal sector activities such as marketing where women are able to help each other with child care. In general, we expect that the likelihood of women's non- family work is lower in the presence of young children than in their absence.

The Ghana Demographic and Health Survey (GDHS) and the Zimbabwe Demographic and Health Survey (ZDHS) were conducted in 1988 (Macro International, 1988.) The second and third waves of GDHS and ZDHS are not available for the same year. These nationally representative sample surveys were part of an international effort to facilitate cross-national studies of demographic behavior and change in developing countries. Therefore, special effort was made to make the data collection procedure and information comparable across countries. 
Most of the variables used here are based upon questions that had the same basic structure in the two countries. The sample sizes for the GDHS and ZDHS are respectively 4,488 and 4,201 women between the ages 15 to 49 years. Thirteen women who had missing values in some of the variables were excluded from the analysis. All the other 8,676 women are used in this study.

\section{Operationalization of Variables}

The survey questions established non-family economic activity as economic enterprise that is not in a business owned by the family or husband. A fivecategory measure for non-family work is constructed by combining information about type and location of current work. Formal work includes professionals, technical and related workers, administrative and managerial workers, clerical and related workers, as well as sales supervisors and buyers, technical salesmen, commercial travel and manufacturer's agents. Domestic informal work includes all other sales workers, service workers and all skilled and unskilled production workers who work at home. Extra-domesticinformal workers include sales workers as well as beverage processors and tailors who sell what they can carry by walking from place to place in a circumscribed area. The categoryalso includes women with occupations similar to those in domestic informal work but who travel from their homes to a work place or market place. We distinguished the itinerant workers in preliminary analyses but they were so few that we decided to combine them with the extra-domestic workers. Non-family work in agriculture includes self-employed as well as agricultural employees. Family employment includes women who work on family businesses or farms.

\section{Family Organization}

Marital status and household headship status are used in combination to measure family organization. Some of the theoretically possible marriage and household head combinationshad to be eliminated because they did not have adequate sample sizes. The six marriage and household categories depict varieties of the conjugal and kin relationship to which women have access. More specifically, six types of mutually exclusive heads of household are considered: (1) married with a coresident spouse who is the head of the household (2) married female head of household with a co-resident spouse, (3) never married single and female head of household, (4) female head of household who was previously married, (5) male head of household with co-resident married couples; and (6) female head of the household with co-resident married couples. Presence of children is a dummy variable coded 1 if the respondent has either one or more children less than five years of age. The number of years of schooling reported by the respondents is used to measure education, the human capital variable. In addition to these three independent variables, we introduce a number of selected control variables. They 
Kofi D. Benefo and Vijayan K. Pillai

are: age of the respondent and place of residence. Age of the respondent is categorized into seven exclusive five-year age intervals between ages 15 and 49 .

Type of residence is a dummy variable with urban coded 1 , and rural 0 . The two countries, Ghana and Zimbabwe, used slightly different definitions of urban. In Ghana, urban areas were localities with populations over 5,000. For Ghana, for example, Owusu (1992) points out that most urban areas are in the population size range of 5,000 to 10,000. In Zimbabwe urban areas had population sizes of at least 2,500 .

\section{Analysis and Results}

Table 1 presents the percentage distribution of the measures employed in the analysis. We begin bivariate analysis of data by examining the distribution of the dependent variable across the four sectors by country and type of place of residence (see Table 2).

Most women are found in family employment but non-family work is still a significant form of economic activity. Its significance varies considerably by place of residence and country. In the urban areas of Ghana, the levels of women's participation in all categories of work except agricultural are high. In Zimbabwean urban areas, the proportion of women in family work is higher than the urban proportion in family work in Ghana. In Ghana the proportions in family work are similar in urban and rural areas. However, in Zimbabwe the proportions in family work are higher than the proportions in non family work in both urban and rural areas. The majority of non-family workers in Ghana are in extra-domestic work while in Zimbabwe, most women are in domestic work.

\section{Multivariate Analysis}

Because the dependent variable is measured categorically, the multinomial logit model is used for its analysis. Multinomial logit models handle polytomous response categories by allowing a comparison of categorical outcomes through a series of contrasts. More generally the concept can be represented as $\log \left(P_{i} / P_{m}\right)=$ $X b_{j}$. The equation specifies the "log of the odds" of being in category $\mathrm{j}$ relative to $\mathrm{m}$ as a function of $X$, a vector of independent variables, and of $b_{j}$, the parameter vector associatedwith category $\mathrm{j}$ (Maddala, 1983). The category ' $\mathrm{m}$ ' is the reference category of the dependent variable. This category consists of 'agricultural work' and 'work in family business.' The two are combined to form the base or reference category. The coefficients, $b_{j}$, are estimated with maximum likelihood. For continuous variables the values of estimated coefficients represent the increment in the $\log$ odds of working for a unit increase in the value of the explanatory variable. The coefficients for categorical variables indicate the increment in the log-odds of working, relative to that for an omitted category. The exponent of a coefficient, 


\section{Table 1}

Descriptive Statistics on Variables for the Ghana and Zimbabwe Samples Combined

\begin{tabular}{|c|c|c|}
\hline Variables & Percent & $\mathbf{N}$ \\
\hline \multicolumn{3}{|l|}{ Type of Work } \\
\hline Formal & 4.52 & 393 \\
\hline \multicolumn{3}{|l|}{ Informal Work } \\
\hline Domestic & 13.58 & 1,180 \\
\hline Extradomestic & 13.51 & 1,174 \\
\hline [Agriculture \& Family Business] & 68.38 & 5,942 \\
\hline \multicolumn{3}{|l|}{ Age } \\
\hline $15-19$ & 21.52 & 1,870 \\
\hline $20-24$ & 19.65 & 1,707 \\
\hline $25-29$ & 17.79 & 1,546 \\
\hline [30-34] & 14.19 & 1,233 \\
\hline $35-39$ & 11.45 & 1,546 \\
\hline $40-44$ & 7.85 & 682 \\
\hline $45-49$ & 7.55 & 656 \\
\hline \multicolumn{3}{|l|}{ Marriage and Household Status } \\
\hline Single & 23.37 & 2,031 \\
\hline \multicolumn{3}{|l|}{ Married and headship } \\
\hline Respondent & 12.68 & 1,102 \\
\hline [Spouse] & 39.96 & 3,211 \\
\hline Other male & 9.68 & 841 \\
\hline Other female & 7.33 & 637 \\
\hline Previously Married & 9.98 & 867 \\
\hline Children less than 5 years & 55.13 & 4,790 \\
\hline Education (Mean years of schooling) & 5.46 & 474 \\
\hline Urban & 33.76 & 2,933 \\
\hline Zimbabwe & 48.35 & 4,201 \\
\hline
\end{tabular}


Table 2

Sectoral Percent Distribution of Respondents by Place of Residence, Women 15 - 49 for Ghana and Zimbabwe

\begin{tabular}{lcc}
\hline \multicolumn{1}{c}{ Type of Work } & Ghana & Zimbabwe \\
\hline Urban & & \\
$\quad$ Formal & 7 & 10 \\
$\quad$ Domestic & 18 & 19 \\
$\quad$ Extra-domestic & 20 & 8 \\
$\quad$ Agriculture & 3 & 1 \\
$\quad$ Family & 52 & 61 \\
$\quad$ & $\mathbf{1 , 5 2 3}$ & $\mathbf{1 , 4 0 3}$ \\
$\mathbf{N} \quad$ & \\
$\quad$ & 3 & 2 \\
Rural & 14 & 8 \\
$\quad$ Formal & 17 & 3 \\
$\quad$ Domestic & 13 & 5 \\
$\quad$ Extra-domestic & 53 & 82 \\
$\quad$ Agriculture & & \\
$\quad$ Family & $\mathbf{2 , 9 6 5}$ & $\mathbf{2 , 7 9 4}$ \\
N $\quad$ & \\
\hline
\end{tabular}

$\exp \left(b_{j}\right)$, is the relative probability or risk of being in one category of the dependent variable versus the omitted. Relative probabilities of risk greater than one mean an increase in the likelihood of the event occurring for a unit increase in the value of a continuous independent variable in comparison to the omitted category of a categorical independent variable. Ratios smaller than one have the opposite interpretation. The results presented in the tables and discussed within the body of the text are based on the more interpretable relative risk ratios. The multivariate analysis is conducted as follows. The first step in the multivariate analysis procedures was to evaluate the model using the Ghana sample. It is well known that urban areas present significantly larger number of opportunities for respondents to engage in extra familial activities than in non-urban areas. For this reason, several researchers suggest that models may be empirically evaluated separately for urban and rural samples (Dewar, Todes \& Watson; 1983; Munachunga, 1989). We tested the model separately for the urban and rural sample populations for Ghana and for Zimbabwe. 
Determinants of Women's Non-family Work in Ghana and Zimbawe

\section{Results}

This section examines the net effects of three proposed determinants of non-family work using the combined Ghana and Zimbabwe samples. The results of the analysis are presented in Table 3.

Previously married women are considerably more likely than other women to be in the labor force. There is no significant difference between the married women with spouse as the head of household and the previously married women in terms of their odds of participating in the formal sector of the labor force. A respondent living in an urban area is about 82 percent more likely than a rural respondent to be engaged in formal sectoral employment than in family business/agricultural employment. Urban residents are significantly more likely to pursue non-family work such as domestic, and extra-domestic work than rural residents. Having children less than five years of age has no significant effect on labor force participation. In general, young women in five-year categories between ages 15 and 29 are significantly less likely to be in the labor force compared to the odds of women in 30-34 age group participating in the labor force.

Next, we examined the influence of the three proposed determinants of non-family work across the two categories of residence, urban and rural, for Ghana and Zimbabwe separately. The odds ratios for Ghana are presented in Table 4.

The age groups 15-19 and 20-24 are combined for the urban analysis because each by itself did not have adequate variation. The nature of family organization has no effect on participation in the formal sector of the labor force. Single women, regardless of their place of residence, are significantly less likely to be in either domestic, or extra-domestic work as compared with married women with coresident spouse who is head of household. The presence of children under age five is likely to constrain participating in the formal sector. Specifically, Ghanian women with children are about 50 percent less likely to participate in the formal sector than in family work. Education has a consistent positive effect on participation in formal sector, domestic and extra-domesticactivities than in family work participation among women who reside in rural Ghana. However, in urban Ghana, education's effect on domestic and extra domestic work are not significant. At young ages, the propensity to engage in non-family work rather than in family work remains low. The odds ratios for age groups below 30 years of age are less than one. The Zimbabwe odds ratios are presented in Table 5. 
Table 3

Odds Ratios for Human Capital, Children and Family Organization Effects, Total Sample, Women 15-49

\begin{tabular}{|c|c|c|c|}
\hline Variable & Formal & Domestic & Extra-Domestic \\
\hline \multicolumn{4}{|l|}{ Age } \\
\hline $15-19$ & $.03 * *$ & $.30^{* *}$ & $.29 * *$ \\
\hline $20-24$ & $.21 * *$ & $.54 * *$ & $.49 * *$ \\
\hline $25-29$ & .89 & $.77 * *$ & .80 \\
\hline [30-34] & -- & -- & -- \\
\hline $35-39$ & 1.46 & 1.13 & 1.15 \\
\hline $40-44$ & 1.64 & .92 & .90 \\
\hline $45-49$ & 2.95 & .97 & 1.05 \\
\hline \multicolumn{4}{|l|}{ Household Headship } \\
\hline Single & .85 & .83 & .80 \\
\hline Resp. & 1.02 & 1.02 & 1.09 \\
\hline [Spouse] & -- & -- & -- \\
\hline Other Male & 1.01 & 1.04 & 1.07 \\
\hline Other Female & .83 & .97 & 1.26 \\
\hline Previously Married & 1.41 & $1.61 * *$ & $2.17 * *$ \\
\hline Children $<5$ yrs & .75 & .92 & .99 \\
\hline Education & $1.68 * *$ & $1.03 * *$ & $1.04 * *$ \\
\hline Urban & $1.82 * *$ & $2.29 * *$ & $2.82 * *$ \\
\hline Zimbabwe & .883 & .474 & $.127 * *$ \\
\hline \multicolumn{4}{|c|}{$\begin{array}{l}\mathrm{N}=8,689 \\
\text { Chi Square }=3014 . .30 \\
\mathrm{P}>\text { Chi Square }=.0000 \\
{[\text { ] omitted category }} \\
* * p>.01 \\
* p>.05\end{array}$} \\
\hline
\end{tabular}




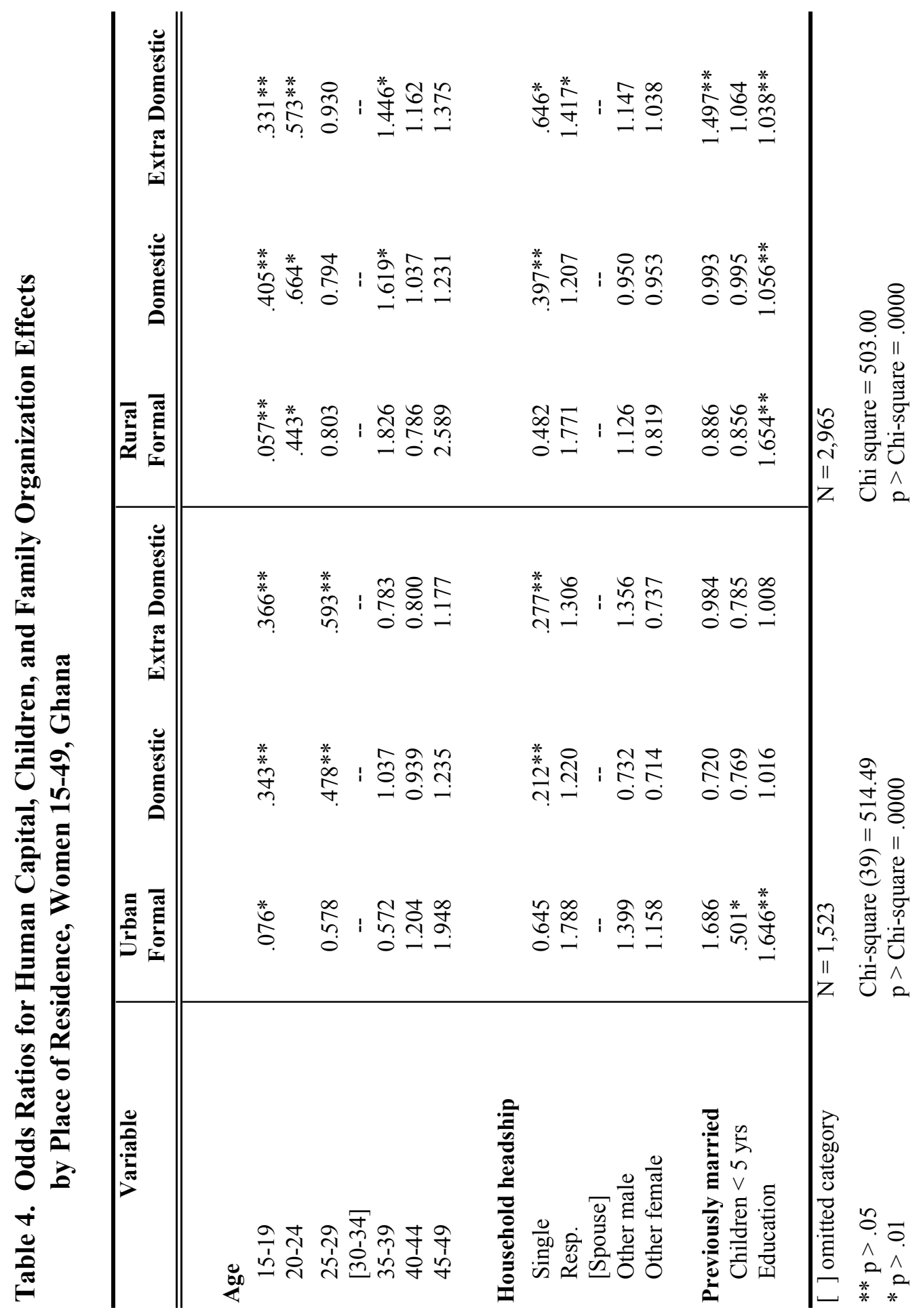


The age groups 15-19 and 20-24 are combined for the urban analysis because each by itself did not have adequate variation. In Zimbabwe the nature of family organization has no effect on participation in the formal sector of the labor force. Single women in the urban areas of Zimbabwe are significantly more likely to be in the extra-domestic sector as compared with married women with co-resident spouses who are head of households. Single women in rural areas of Zimbabwe, however, are significantly less likely to be in the domestic sector than in family work as compared with a married respondent with a spouse who is the head of the household. Presence of children under age five has no significant effect on nonfamily work. Education has a positive effect as hypothesized on non-family work participation. Among urban respondents, education increases the likelihood of formal sector participation and does not significantly influence the likelihood of participation in domestic and extra-domestic sectors. In rural areas, education increases the likelihood of participation in formal and domestic sectors. It does not increase but decreases the odds of participating in the extra-domestic sector in relation to the odds of engaging family work.

The odds ratios for the three proposed determinants of non-family work are in general similar across the two countries, Ghana and Zimbabwe. In both countries, among urban residents, education has a positive effect on participation in the formal sector. Among urban respondents, the odds of participation with a unit increase in education, in either the extra-domestic or domestic sectors are not significantly different from being involved in family work alone. This result holds for both Ghana and Zimbabwe. Among rural respondents, however, education in general increases the likelihood of being engaged in either extra-domestic or domestic work. This is true for Ghana and Zimbabwe with the exception that education significantly decreasesthe likelihood of being involved in extra-domestic work in Zimbabwe.

The presence of children under age five has no significant influence on non-family work in both countries. In Ghana, however, the presence of children significantly reduces the participation in formal sector jobs. The role of kin relationships in securing extra-domestic and domestic jobs decreases with urbanization. The effects of family organization on non-family work are not similar for Ghana and Zimbabwe. In both countries, the role of kinship relationships in formal sectoral participation is not important in increasing the likelihood of formal sector participation. Generally, in Zimbabwe kin appear to play a role in improving the likelihood of participating in either domestic or extra-domestic activities in the urban areas. For example, in Zimbabwe, the likelihood of participating in extradomestic work among urban householders is at least six times more than the odds of participating in family work alone. Being single in Ghana considerably reduces the likelihood of participation in domestic/extra-domestic work in both urban and rural areas. In Zimbabwe, single women are significantlymore likely to be in extradomestic work rather than in family work, in both rural and urban areas. 


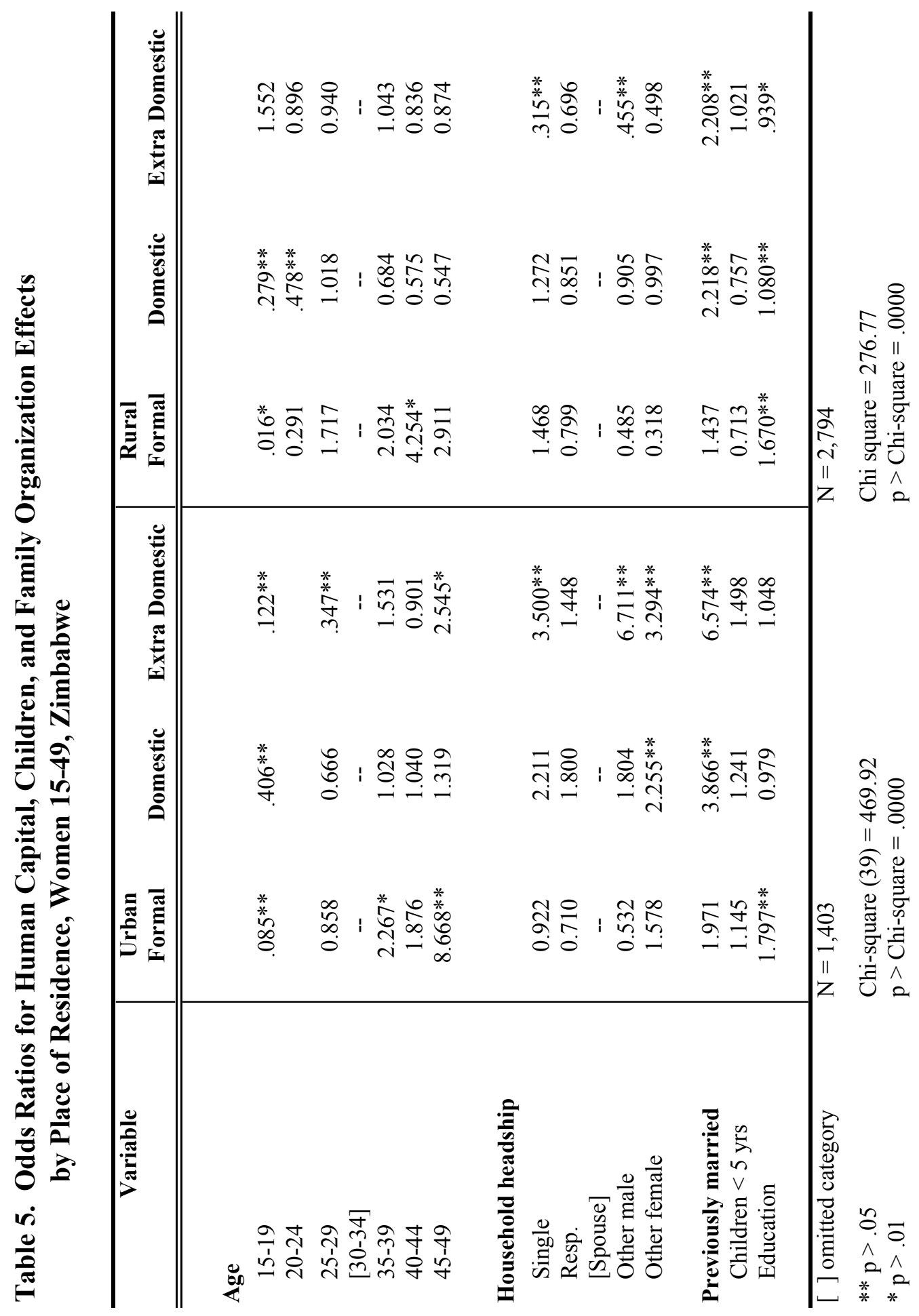


Kofi D. Benefo and Vijayan K. Pillai

In sum, empirical findings provide mixed support for the three proposed explanations of family work. The human capital theory, which suggests that education significantly increases the likelihood of formal work participation, is supported. The argument that children below five years of age reduce the likelihood of formal sector participation is partially supported. In general, the presence of young children appears not to significantly influence the likelihood of participation in extra familial work such as domestic and extra-domestic activities. However, in Ghana the presence of young children reduces the likelihood of formal sector participation. The family organization explanation, the role of kin relations, is not supported by Ghanaian data. Even in Zimbabwe, the effects of kin relations are minimal, mostly confined to non-formal sector work among urban respondents.

With improvements in female education, women are likely to participate in the informal as well as the formal economic sectors. However, informal economies in Africa are organized and managed by kinship-based networks with predominantly high male representation. Entry into the informal economy for women, especially in the rural areas, is likely to be influenced by informal rules that are patriarchal and kin-based. As more and more families become female headed, the presence of young children hinders women's ability to enter the formal economy. Once these women enter into the informal economy, their ability to negotiate reasonable wages and security may be constrained because of the importance of kin-based social networks in the management of the informal economies. Programs to improve women's education should be coordinated with work laws that are necessary to prevent large scale exploitation of women's labor especially in the rural areas.

\section{Conclusion}

The goals of this paper are to empirically examine the determinants of female nonfamily work in Africa and to evaluate the generalizeability of the findings using a comparative study approach. The findings are influenced by the amount of error in the measurement of the dependent variable, non-family work. The structure of sustenance organization in Ghana is to a very large extent family oriented such that apart from formal employment, the family permeates every aspect of women's life. We evaluated three arguments of female labor force participation using demographic and health survey data from Ghana and Zimbabwe. The fact that heads of lineages and kinship groups have the power to control women's economic, and social opportunities, has implications for women's labor force participation. The traditional kinship-orientedfamily organization in Africa, along with high fertility, have long been seen as factors which constrain women's participation in the labor force, particularly in seeking formal sector employment. These expectations are not empirically supported. Education emerges as the most important determinant of non-family work. Kinship and lineage statuses may be used to access domestic and extra-domestic work within the informal economy. This influence of traditional family structure is not diminished by urbanization. The relationship between 
family structure and informal economy is complex and needs further investigation.

This study faults the unidimensional focus of the policies. A significant feature of these policies is their singular focus on specific determinants of non-family work. This study argues that a variety of factors, encompassing education, urbanization and family organization govern non-family work. To seriously address women's participation in formal sectoral employment, policy needs to target all aspects of the problem in a comprehensive manner. Family planning policies, for instance, attempt to reduce family size in order to enable women to enter the labor market, under the assumption that it is women with wider kin relationships that are handicapped. What this research shows is that the non-conjugal relationships become more important in affording access to non-family resources in the informal sector. Continuing focus on women's education is likely to improve women's formal sectoral employment. Unfortunately, in Africa a number of school and family related problems result in higher dropout rates for girls than for boys (Achola \& Pillai, 2001).

\section{References:}

Abu-Hussein, A.E. 1994. "A probabilistic model for studying factors affecting female employment," Egyptian Population and Family Planning Review 28(2): 162-182.

Achola, PW and V.K. Pillai. 2001. Challenges of Primary Education in Developing Countries: Insights from Kenya. Aldershot: Ashgate Publishers.

Adepoju, A. 1994. "Women, work, and fertility in Swaziland." In Gender, Work, and Population in Sub Saharan Africa, edited by Adepoju, A. and C. Oppong. London: James Currey.

Afonja, S. 1981. "Changing modes of production and the sexual division of labor among the Yoruba," Journal of Women, Culture and Society 7(2): 299-313.

Boserup E. 1970. Women's Role in Economic Development. London: Allen \& Unwin.

Central Statistical Office. 1988. Ghana Demographic and Health Survey. Accra: $\mathrm{CSO}$

Central Statistical Office. 1988. Zimbabwe Demographic and Health Survey. Harare: CSO 
Kofi D. Benefo and Vijayan K. Pillai

DaVanzo, J. and L.P. Lee. 1978. The compatibility of childcare with labor force participation and nonmarket activities: Preliminary evidence from the Malaysian time budget data. The Rand Paper Series P-6126, Santa Monica, California: The Rand Corporation.

Davison, J. 1988. "Land and women's agricultural production: The context." In Agriculture, Women and Land: The African Experience, edited by Jean Davison. Boulder and London: Westview Special Studies on Africa.

Dewar, D., A. Todes and V. Watson. 1983. "Urbanization processes and policies in Africa," Journal of Contemporary African Studies 3(1-2):79-109.

Edwards, S. 1996. "Schooling's fertility effect greatest in low literacy, high fertility societies, InternationalFamily Planning Perspectives 22(1): 43-44.

Ettiene, M. 1983. "Gender relations and conjugality among the Baule." In Female and Male in West Africa, edited by C. Oppong. London: George Allen and Unwin.

Haghighat, E. 2002. "Culture, development and female labor force participation: Disaggregating different sectors," International Review of Sociology 12(3): 343-362.

Hart, K. 1973. "Informal income opportunities and urban employment in Ghana." Journal of Modern African Studies (11): 68.

International Labor Organization. 1964. The Employment and Conditions of Work of African Women. Geneva: ILO.

Jensen, A.M. 1995. "The status of women and the social context of reproduction," Journal of International Development 7(1): 61-79.

Jibou, R. 1988. "Ethnic hegemony and the Japanese of California," American Sociological Review 53(3): 353-367

Junsay, A.T. and T.M. Heaton. 1989. Women Working: Comparative Perspectives in Developing Areas. New York, NY: Greenwood Press.

Kanduza, E. 1988. Female head of households in Zambia, Masters Thesis. Iowa City, IA: University of Iowa.

Khattab, N. 2002. "Ethnicity and female labour market participation: A new look at the Palestinian enclave in Israel," Work, Employment and Society 16(1): $91-110$ 
Kossoudji,S. and E. Mueller. 1981 The economic and demographic status of female headed households in Rural Botswana: Research report no. 81-10 Ann Arbor, MI: University of Michigan, Population Studies Center.

Leis, N.B. 1974. "Women in groups: Ijaw women's associations." In Women, Culture and Society, edited by M.Z. Rosaldo and L. Lamphere. Stanford: Stanford University Press.

Lewis, B.C. 1977. "Economic Activity and Marriage among Ivorian Urban Women." In Sex Stratification: A Cross Cultural View, edited by A. Schlegel. New York, NY: Columbia University Press.

Macro-International. 1988. Demographic and health surveys. Maryland: MacroInternational.

Maddala, G.S. 1983. Limited-development and Qualitative Variables in Econometrics. Cambridge: Cambridge University Press.

Mueller, E. 1982. "The allocation of women's time and its relation to fertility." In Women's Status and Fertility, July 8-11, edited by R. Anker, M. Buvinic and N. Youssef. New York: NY.

Munachunga, M. 1989. Some social and cultural aspects of fertility in contemporary Zambia. In Population and Development in Zambia, proceedings of the National Conference on Population Policy, and the Interagency seminar on Zambia's population policy, implementation strategy, May 17-19, 1989. Prepared by the office of the president, National Commission for Development Planning, Republic of Zambia, Lusaka, Zambia, Zambia National Commission for Development Planning 1989: Aug. 27-40.

Naude, W. and P. Serumaga-Zake. 2001. "An analysis of the determinants of labour force participation and unemployment in South Africa's Northwest Province," Development Southern Africa 18(3): 261-278

Nukunya, G.K. 1975. “The family and social change." In Colonialism and Change: Essays to Professor Lucy Mair, edited by M. Owusu. The Hague: Mouton.

Nukunya, G.K. 1992. Tradition and Change. Accra: Ghana Universities Press.

Ogawa, N. and J.F. Ermish. (1996). "Family structure, home time demands, and the employment patterns of Japanese married women," Journal of Labor Economics 14(4): 677-702 
Kofi D. Benefo and Vijayan K. Pillai

Owusu, M. 1992. "Democracy and Africa: A view from the village," The Journal of African Studies 30(3): 369-396.

Parrado, E.A. and R.M. Zenteno. 2001. "Economic restructuring, financial crises, and women's work in Mexico," Social Problems 48(4): 456-477.

Pedersen, J. 1987. "Plantation women and children: Wage labor, adoption, and fertility in the Seychelles," Ethnology 26(1): 51-61.

Peil, M. 1972. The Ghanian Factory Worker: Industrial Man in Africa. Cambridge: Cambridge University Press.

Safilios-Rothschild, C. 1985. The status of women in fertility in the Third world in the 1970-1980decade. Center for Policy Studies working paper, No. 118: The Population Council.

Sanjek, R. 1982. "The organization of households in Adabraka towards a wider comparative perspective," Comparative Studies in Society and History 24(1): 57-13.

Sarpong, P. 1974. Ghana in Retrospect. Accra-Tema: Ghana Publishing House.

Schildkrout, E. 1979. "Women's work and children's work." In Social Anthropology of Work, edited by S. Wallman. London: ASA Monograph 19.

Standing, G. 1983. "Women's work activity and fertility." In Determinants of Fertility in Developing Countries, edited by R.A. Bulatao and R.D. Lee. New York, NY: Academic Press.

Stycos, J.M. and R.H. Weller. 1967. "Female working roles and fertility," Demography 4(1): 210-217.

Sudarkasa, N. 1982. "Female employment and family organization in West Africa." In Anthropology for the Eighties: Introductory Reading, edited by J.B. Cole. New York, NY: Free Press.

Togunde, O.R. 1999a. "Determinants of women's employment in Urban Nigeria: The impact of socio cultural factors," Journal of Asian and African Studies 34(3): 279-297.

Togunde, O.R. 1999b. "A social structural analysis of the effects of women's employment on fertility in urban Nigeria," Journal of Developing Societies 15(2): 172-188. 